\title{
On the fate of old stored carbon after large-infrequent disturbances in plants
}

Rodrigo Vargas

Department of Environmental Science, Policy and Management; University of California; Berkeley, CA USA

Key words: fine roots, radiocarbon, mycorrhizae, carbon reserves, hurricane, plant stress

Plants have the capacity to store and reallocate stored nonstructural C, but little is known about the age and ecological roles of these pools. It was thought that plants allocate recently assimilated $\mathrm{C}$ to produce new fine roots. However, there is recent evidence that plants can allocate old stored $\mathrm{C}$ for the production of fine roots following a large-infrequent disturbance (LID) providing a new dimension of the fate and the implied role of stored $\mathrm{C}$ in plants. Here, I explore other possible adaptations of plants to allocate stored $\mathrm{C}$ reserves, and provide a series of open questions on the fate of old stored C in plants. Specifically, I propose that another metabolic function of old stored $\mathrm{C}$ may be for supporting mycorrhizal fungi colonization after a largeinfrequent disturbance, because the production of hyphae may be more economical in terms of $\mathrm{C}$ to the plant under stressful conditions. Finally, in order to better understand plant resilience to LIDs it is critical to understand the mechanisms that regulate the fate of old stored $\mathrm{C}$ in plants.

Plants have the capacity to store non-structural C, but little is known about the sizes, ages and ecological roles of these pools. Radiocarbon $\left({ }^{14} \mathrm{C}\right)$ dating has shown that plants allocate recently assimilated $\mathrm{C}$ to produce new fine roots in temperate, ${ }^{1,2}$ and tropical forests. ${ }^{3}$ However, Vargas et al. ${ }^{4}$ provided evidence that plants can allocate old stored C (up to 11 years in mature forests) for the production of fine roots following a large-infrequent disturbance (LID), and provided a new dimension of the fate and the implied role of stored C in plants. Here, I present new data on a young forest stand and explore other possible adaptations of plants to allocate stored $\mathrm{C}$ reserves, and provide a series of questions for further lines of research in plant physiology and plant biochemistry research in this regard.

Correspondence to: Rodrigo Vargas; Department of Environmental Science, Policy and Management; University of California; Berkeley, CA USA; Tel.: 1.510.642.2421; Fax: 1.510.643.5098; Email: rvargas@nature.berkeley.edu

Submitted: 04/30/09; Accepted: 05/01/09

Previously published online as a Plant Signaling \& Behavior E-publication: http://www.landesbioscience.com/journals/psb/article/8906

Addendum to: Vargas R, Trumbore S, Allen MF. Evidence of old carbon used to grow new fine roots in a tropical forest. New Phytol 2009; 182:710-8; PMID: 19434807; DOI: 10.1111/j.1469-8137.2009.02789.x.
The study was conducted at El Eden Ecological Reserve (lat $21^{\circ} 12.6^{\prime} \mathrm{N}$, long $87^{\circ} 10.93^{\prime} \mathrm{W}$ ) in the northeast Yucatan Peninsula, Mexico. The study site is a seasonally dry tropical forest where recurrent LIDs (e.g., fires and hurricanes) have created a landscape of forests of different ages. ${ }^{5,6}$ During September and December of 2005, nine soil cores were collected at a 16-year old forest stand as described in Vargas et al. ${ }^{4}$ The soil cores were sieved through a $2 \mathrm{~mm}$ mesh and fine roots were sorted by hand to determine AM colonization and radiocarbon $\left({ }^{14} \mathrm{C}\right)$ values of live roots. Additionally, root in-growth cores were buried $(10 \mathrm{~cm}$ depth) in duplicates at the forest stand. Sieved and clean fine roots were prepared for analysis of percentage colonization of AM structures ${ }^{7}$ (e.g., hyphae, arbuscules and vesicles). Radiocarbon $\left({ }^{14} \mathrm{C}\right)$ was used to estimate the mean age of structural C in fine roots. Briefly, roots were treated with an acid-base-acid procedure to remove nonstructural $\mathrm{C}$, oven dried at $65^{\circ} \mathrm{C}$ and then ground following previous studies. ${ }^{1,4}$

Radiocarbon values of structural $\mathrm{C}$ in live roots before the hurricane showed that these roots were produced from recently fixed photosynthetic products $\left(\Delta^{14} \mathrm{C}\right.$ mean $\left.72.7 \% \pm \mathrm{SD} 5.8\right)$. In contrast, we found that new roots produced up to two months after the hurricane event had a large variation in their $\Delta^{14} \mathrm{C}$ values (mean $80.2 \% \pm$ SD 14.2; Fig. 1) with $\Delta^{14} \mathrm{C}$ values up to $101 \%$ which are equivalent to $C$ fixed nearly 6 years ago (Fig. 1). This young forest has nearly 100 trees ha ${ }^{-1}$ with trees with a diameter at breast height $(\mathrm{DBH})$ larger than $10 \mathrm{~cm}$ as described in a previous study. ${ }^{8}$ Mycorrhizae colonization before the hurricane was nearly $61.5 \%$, and it significantly increased ( $\mathrm{t}$-test; $\mathrm{p}=0.022$ ) to $83.4 \%$ after the hurricane (Fig. 2).

The radiocarbon results presented here add to the previous published results by Vargas et al. ${ }^{4}$ on that young forests have the capacity to allocate stored old C (up to 6 years old) for production of fine roots after LIDs, but the variability on the radiocarbon values in new fine roots is larger than in mature forests. ${ }^{4}$ The results presented here and in Vargas et al. ${ }^{4}$ open a series of questions of the fate of old stored $\mathrm{C}$ that may be asked by different scientists across the plant sciences: Which is the minimum size/ volume of a plant to be able to store non-structural $\mathrm{C}$ and allocate it for new structures after stressful conditions? For how long can non-structural C pools reside within plants and does plant size, 


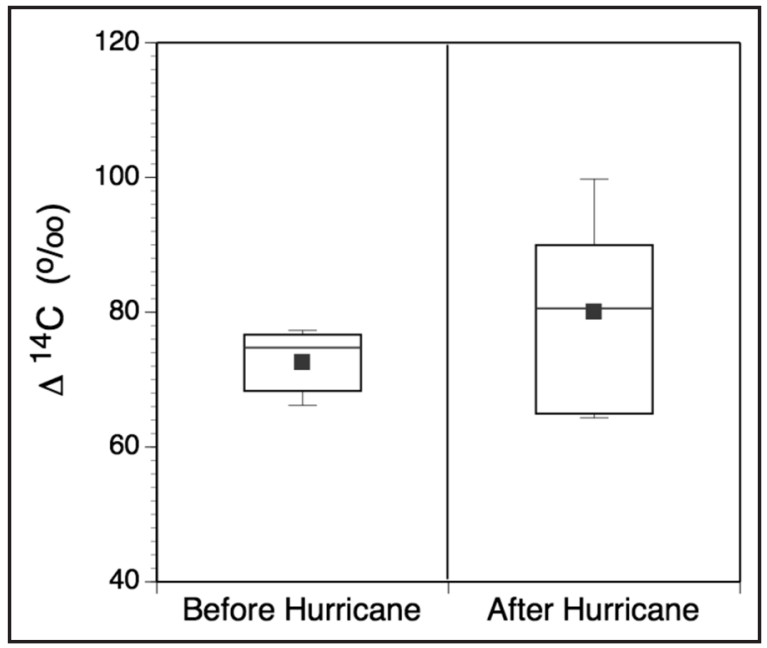

Figure 1. Radiocarbon values in fine root structural tissues of fine roots $\mid<2$ $\mathrm{mm}$ ) sampled before Hurricaine Wilma and of new fine roots produced up to 2 months after the hurricane using $\Delta^{14} \mathrm{C}$ of $\mathrm{CO}_{2}$. Box plots represent the values for three samples at a young forest stand in a tropical forest, Mexico.

plant volume or plant functional type (e.g., shrubs, trees) influence the residence time of these $\mathrm{C}$ pools? What are the biochemical pathways and genetic mechanisms that trigger the allocation of old stored C? Are these mechanisms similar across species, functional types and biomes (e.g., boreal vs. tropical areas)? Which are other metabolic functions of old $\mathrm{C}$ reserves in plants?

I propose that another metabolic function of old stored $\mathrm{C}$ in plants may be the allocation of old $\mathrm{C}$ to support mycorrhizal fungi colonization after a LID. These fungi are obligate symbionts that form a mutualistic relationship with plant roots known as mycorrhiza. The fungi can receive between 3 and $22 \%$ of gross primary production (GPP) from their host plants ${ }^{9,10}$ in exchange for nutrient transfer to roots that benefit plant growth. It is known that increases in mycorrhizal colonization may help plants take up nutrients and water that in turn benefit plant development. ${ }^{11}$ In general, neotropical forests are mainly dominated by arbuscular mycorrhizal (AM) fungi, ${ }^{12}$ but we know little about the effect of LIDs on AM colonization. Defoliation and root mortality induced by LIDs represents a $\mathrm{C}$ cost to plants that may reduce GPP and photosynthate use to support roots and mycorrhizae. Thus, previous studies have found that defoliation and herbivory reduces AM colonization due to a loss in photosynthetic area. ${ }^{13,14}$

With nearly $50 \%$ reduction in root biomass and defoliation following hurricane Wilma ${ }^{4}$ plants needed to invest $\mathrm{C}$ to produce new fine roots and new leaves that may divert $\mathrm{C}$ to maintain $\mathrm{AM}$ colonization. Contrary to expectations, the results show that AM root colonization increased following the hurricane in this young tropical forest (Fig. 2). Following the hurricane, decomposition of the organic matter deposited by plant defoliation should have been fast due to high soil moisture and high $\mathrm{N}$ content in the fresh organic matter. ${ }^{6}$ Furthermore, this pulse in nutrients may only be available for a short time so plants must maximize the capacity to absorb nutrients under stressful conditions imposed by the LID. It has been hypothesized that $\mathrm{C}$ allocation to $\mathrm{AM}$ colonization

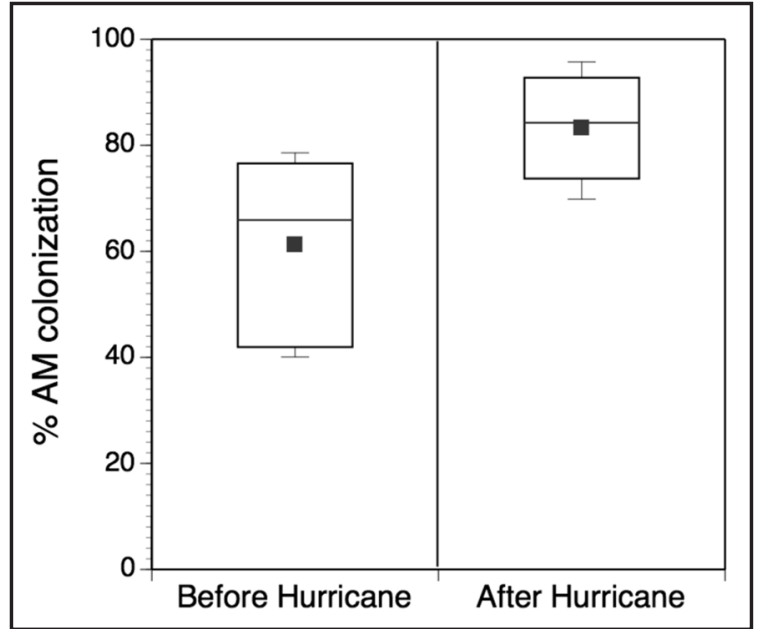

Figure 2. Arbuscular mycorrhizae (AM) root colonization (in percent, \%) sampled before and up to 2 months after the hurricane Wilma. Box plots represents the values for six samples at a young forest stand in a tropical forest, Mexico.

instead of the root system is promoted because the production of hyphae is more economical in terms of $\mathrm{C}$ than the production of an equivalent length of fine root. ${ }^{15}$ Thus, the results presented here suggest the possibility that stored non-structural C pools may be used to supply $\mathrm{C}$ not only for production of fine roots but also to support and increase AM root colonization.

Although C reserves (i.e., non-structural C) in plants were not measured directly, the results suggest that the most likely explanation is that plants have the capacity to re-allocate stored $\mathrm{C}$ for production of new fine roots and likely to support mycorrhizae colonization. These results complement the observations that plants allocate stored $\mathrm{C}$ pools for root and mycorrhizae following fire disturbances, ${ }^{16}$ and provide insights of other metabolic functions of stored C. The capacity of plants to allocate old C for plant structures that will enhance water and nutrient uptake may be an adaptation of plants in systems subject to LIDs.

I have presented multiple questions that arise on the fate of stored C in plants after LIDs that may inspire plant scientists to look into the fate of these pools. Finally, if plants have the capacity to allocate stored $\mathrm{C}$ under stressful conditions, what is the fate of these pools and how these physiological mechanisms will be influenced by changing climatic conditions? If the intensity of fires and hurricanes increase, as is predicted by global climate change models, then plants could deplete these reserve pools that will influence their resilience to LIDs. Thus, in order to better understand plant and ecosystem recovery to LIDs, it is critical to understand the mechanisms that regulate the fate of old stored C in plants.

\section{Acknowledgements}

I am grateful for help from El Eden Ecological Reserve in the provision of technical support. Susan Trumbore and Xiaomei Xu provided invaluable assistance in preparing the samples for ${ }^{14} \mathrm{C}$ analysis. This work was made possible through funding from Consejo Nacional de Ciencia y Tecnología and University of California 
Institute for Mexico and the United States. While writing the manuscript, R.V. was supported by grant DEB-0639235.

\section{References}

1. Gaudinski JB, Trumbore SE, Davidson EA, Cook AC, Markewitz D, Richter DD. The age of fine-root carbon in three forests of the eastern United States measured by radiocarbon. Oecologia 2001; 129:420-9.

2. Joslin JD, Gaudinski JB, Torn MS, Riley WJ, Hanson PJ. Fine-root turnover patterns and their relationship to root diameter and soil depth in a C-14-labeled hardwood forest. New Phytol 2006; 172:523-35.

3. Trumbore S, Da Costa ES, Nepstad DC, De Camargo PB, Martinelli L, Ray D, et al. Dynamics of fine root carbon in Amazonian tropical ecosystems and the contribution of roots to soil respiration. Global Change Biology 2006; 12:217-29.

4. Vargas R, Trumbore $S$, Allen MF. Evidence of old carbon used to grow new fine roots in a tropical forest. New Phytol 2009; 182:710-8.

5. Vargas R, Allen MF, Allen EB. Biomass and carbon accumulation in a fire chronosequence of a seasonally dry tropical forest. Global Change Biol 2008; 14:109-24; doi:10.1111/j.365-2486.007.01462.x.

6. Vargas R, Allen MF. Diel patterns of soil respiration in a tropical forest after Hurricane Wilma. J Geophys Res-Biogeosci 2008; 113:3021.

7. McGonigle TP, Miller MH, Evans DG, Fairchild GL, Swan JA. A new method which gives an objective measure of colonization of roots by vesicular-arbuscular mycorrhizal fungi. New Phytol 1990; 115:495-501.

8. Vargas R, Allen EB, Allen MF. Effects of vegetation thinning on above- and belowground carbon in a seasonally dry tropical forest in Mexico. Biotropica 2009; 41:302-11.

9. Johnson D, Leake JR, Ostle N, Ineson P, Read DJ. In situ $13 \mathrm{CO}_{2}$ pulse-labelling of upland grassland demonstrates a rapid pathway of carbon flux from arbuscular mycorrhizal mycelia to the soil. New Phytol 2002; 153:327-34.

10. Hobbie EA. Carbon allocation to ectomycorrhizal fungi correlates with belowground allocation in culture studies. Ecology 2006; 87:563-9.

11. Smith SE, Read DJ. Mycorrhizal symbiosis. Amsterdam; Boston: Academic Press 2008.

12. Allen EB, Allen MF, Helm DJ, Trappe JM, Molina R, Rincon E. Patterns and Regulation of Mycorrhizal Plant and Fungal Diversity. Plant Soil 1995; 170:47-62.

13. Gange AC, Bower E, Brown VK. Differential effects of insect herbivory on arbuscular mycorrhizal colonization. Oecologia 2002; 131:103-12.

14. Wearn JA, Gange AC. Above-ground herbivory causes rapid and sustained changes in mycorrhizal colonization of grasses. Oecologia 2007; 153:959-71.

15. Jakobsen SE, Smith SE, Smith FA. Function and diversity of arbuscular mycorrhizae in carbon and mineral nutrition. In: van der Heijden MGA, Sanders I, eds. Mycorrhizal ecology. Berlin: Springer-Verlag 2002; 75-92.

16. Langley JA, Drake BG, Hungate BA. Extensive belowground carbon storage supports roots and mycorrhizae in regenerating scrub oaks. Oecologia 2002; 131:542-8. 